\title{
Variations in consumer's acceptability and proximate composition of yellow croaker (Larimichthys polyactis) with processing methods
}

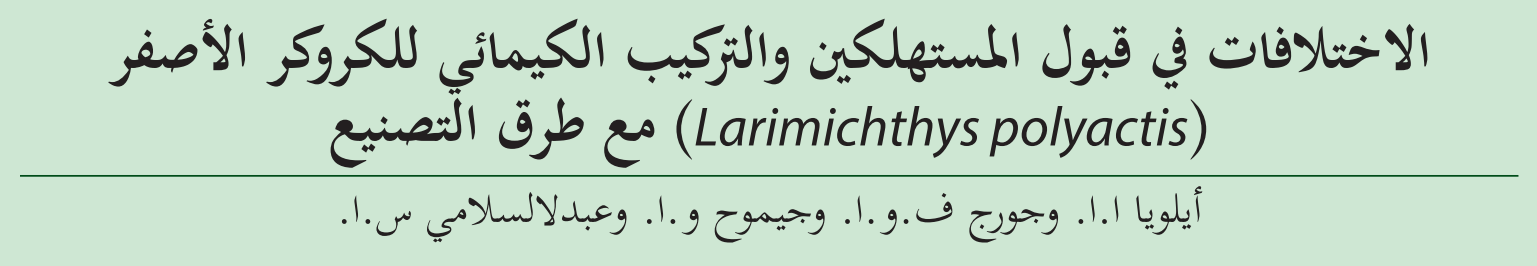

AвSTRACT. The effect of processing methods on the proximate composition and consumer's acceptability of yellow croakers were investigated. The experiment followed a completely randomized design with several processing methods. Frozen yellow croaker fish of $12 \mathrm{~kg}$ were purchased, cut into chunks, divided into 4 groups of $3 \mathrm{~kg}$ each, each group was salted and then subjected to different processing methods including: air drying in the sun, deep-frying, solar drying and smoking. After processing, the products were subjected to organoleptic assessment using an hedonic scale while the proximate composition was determined using standard experimental procedures. The results of this study indicated that the odour and flavour of smoked fish product were significantly $(\mathrm{p}<0.01)$ preferred by consumers. Solar dried fish product had highest percentage crude protein $(71.45 \mathrm{~kg} / 100 \mathrm{~kg}$ sample) followed by smoked fish product $(70.43 \mathrm{~kg} / 100$ $\mathrm{kg}$ sample) while smoked fish product had the highest crude ash $(10.73 \mathrm{~kg} / 100 \mathrm{~kg}$ sample). The study suggested that it was better to process quality yellow croaker using solar dryers and smokers to attract customers.

KEYWORDS: Consumers; proximate composition; processing methods; yellow croaker.

$$
\begin{aligned}
& \text { المستخلص: تم دراسة تأثير طرق التصنيع على التركيب الكيميائي وقبول المستهلك لسمكك الكرور الأصفر. ـ وقد إتبعت التجربة تصميمًا إحصائيا }
\end{aligned}
$$

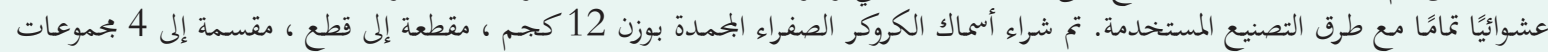

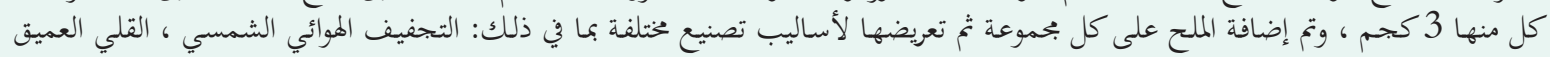

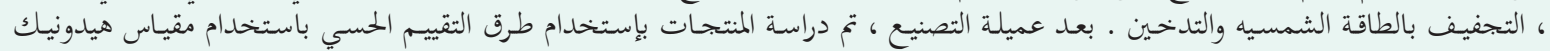

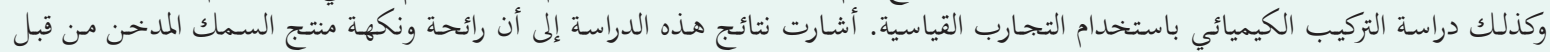

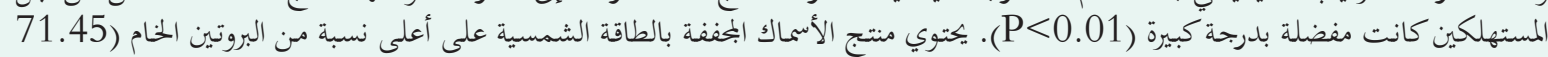

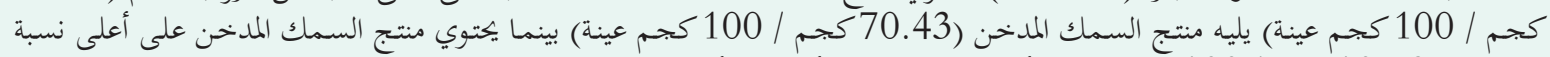

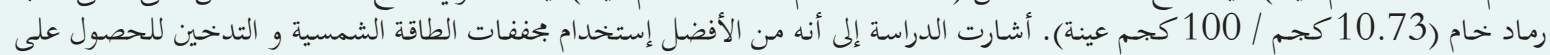

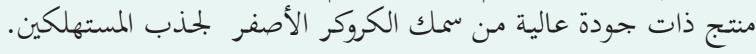

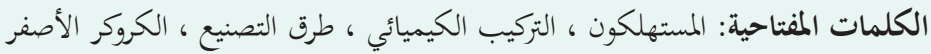

\section{Introduction}

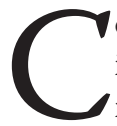

onsumers have become increasingly interested in fish as a source of dietary protein due to the rising cost of meat protein foods (Emere and Dibal, 2013). Fish as a whole, has a lot of food potential and can therefore be expected to provide relief from malnutrition, especially in developing countries (Ashraf et al., 2011). It constitute about $60 \%$ of the total protein intake in adults especially in rural areas (Adeleye, 1993). Foran et al. (2005) pointed that fish is a highly protein containing food consumed by a larger percentage of population because of its availability and palatability. In Nigeria, fish is eaten fresh, preserved or processed (smoked) and form a much-cherished delicacy that cuts across socio-economic, age, religious and educational

A. A. Ayeloja ${ }^{1}(\longrightarrow)$ ayeloja2@gmail.com, Department of Aquaculture and Fisheries, University of Ilorin, PMB 1515 Ilorin, Kwara State, Nigeria barriers (Adebayo-Tayo et al., 2008). However, the gap between demand and supply of fish is widening due to increase in population, poor postharvest handling, lack of processing and storage facilities and utilization of unconventional fish species (Ogbonnaya and Ibrahim, 2009). Different fish processing and preservation methods are used to slow down spoilage resulting in fish that are both be safer for consumption and with an increased shelf-life. Researchers have also studied the effect of processing methods on the nutritional qualities of different fish species. Nutritive and organoleptic changes of Nigerian traditionally-processed freshwater fish species were studied by Afolabi et al. (1984). The effect of traditional drying processes on the nutritional values of fish was studied by Eves and Brown (1993). Changes in chemical composition and nutritional quality of fried Sardine (Clupea pilchardus) produced by frozen storage and microwave reheating were reported by Castrillon et al. (1997). Ayeloja et al. (2013) reported the effect 
Table 1. Effect of processing methods on the perceived physical attributes (hedonic scale) of yellow croaker.

\begin{tabular}{|c|c|c|c|c|c|c|c|c|c|}
\hline Fish products & Odour & $\begin{array}{c}\text { Kruskal-Wallis } \\
\left(\chi^{2}\right)\end{array}$ & $\mathrm{p}$-value & Flavour & $\begin{array}{c}\text { Kruskal-Wallis } \\
\left(\chi^{2}\right)\end{array}$ & p-value & Texture & $\begin{array}{c}\text { Kruskal-Wallis } \\
\left(\chi^{2}\right)\end{array}$ & p-value \\
\hline Sun dried & 25.65 & $36.836^{* *}$ & 0.01 & 20.59 & $40.705^{* * *}$ & 0.01 & 36.76 & 3.932 & 0.27 \\
\hline Fried & 53.38 & & & 52.68 & & & 28.56 & & \\
\hline Solar dried & 16.47 & & & 18.53 & & & 31.85 & & \\
\hline Smoked & 42.50 & & & 46.21 & & & 40.82 & & \\
\hline
\end{tabular}

*Kruskal Wallis test $\left(\chi^{2}\right)$ is significant between rows at $p<0.05$

of processing methods on the nutritive value of catfish (Clarias gariepinus). However, there is little information on the effect of processing methods on the nutritional quality of Yellow croaker, thus the need for this study.

Schiffman and Graham (2000) reported that taste and smell played an important role in developing appetite, making food choices, and nutrient intake for the following reasons: (1) these chemosensory signals prepare the body to digest food by triggering salivary, gastric, pancreatic, and intestinal secretions, which are termed cephalic phase responses, (2) they enable us to detect and discriminate among foods in the face of fluctuating nutritional requirements. Taste and smell enable selection of a nutritious diet as there are associations between a food taste or smell and its post-ingestion effects as taste enable the consumer to modulate food intake in anticipation of its nutritional consequences. Thus, taste sensations serve as an indicator of a particular food nutritional value. In addition, taste and smell signals initiate, sustain and terminate ingestion, and hence play a major role in the quantity of food that is eaten and the size of meals. Taste sensations induce feelings of satiety and are primary reinforced by eating. Thereby, justifying the use of texture, odour and flavour (which is a combination of taste and odour) in determining consumers' acceptability of various food, in this case differently processed yellow croaker.

\section{Materials and methods}

The experiment followed a completely randomized design where the treatments were the various processing methods employed. Twelve $(12 \mathrm{~kg})$ frozen yellow croaker fish was purchased from the cold room of Atlantic Shrimpers limited, Ring Road, Near Challenge Roundabout, Ibadan Oyo State, Nigeria. These were transported within 17 minutes to the fish processing unit of Federal College of Animal Health and Production Technology (FCAH \& PT) Moor Plantation, where these were cut into chunks and then divided into 4 groups of $3 \mathrm{~kg}$ each. Each chunk was washed, salted and then subjected to different processing methods including: air drying in the sun (sun drying), deep-frying, solar drying (in a solar oven) and smoking. Sun drying was done for 4 days using locally constructed sun drying rack with appropriate screen, which protected the product from direct contact with insects. The average ambient temperature during the period of the experiment was $27^{\circ} \mathrm{C} \pm 3^{\circ} \mathrm{C}$. Deep-frying was performed in vegetable oil in a pot on a hot flame with occasional flipping in order to achieve even frying. Frying was achieved within 21 minutes at a temperature of about $240^{\circ} \mathrm{C}$. Solar drying was achieved in 4 days using locally constructed solar dryer with appropriate screen, which protected the product from direct contact with insects. Smoking was done at the temperature of $90^{\circ} \mathrm{C} \pm 10^{\circ} \mathrm{C}$ for 42 hours using NIOMR (Nigeria Institute for Oceanography and Marine Research) smoking kiln installed in the fish processing unit of the Fisheries Technology Department, Federal College of Animal Health and Production Technology (FCAH \& PT) Moor Plantation Ibadan Oyo State Nigeria. Charcoal was used to generate heat and smoke.

The various processed fish products were subjected to sensory quality evaluation using descriptive test based on 5-point hedonic scale modified from Tobor (1994) and Eyo (2001). Odour, flavour and texture were the sensory attributes examined. The following grades were allotted depending on their qualities: $8-10=$ Excellent, $6-8=$ Very good, $4-6=$ good, $2-4=$ bad and $\leq 2=$ worst. Twelve trained panelists from the Federal College of Animal Health and Production Technology Ibadan were used for the assessment. The proximate composition of the fish samples was determined using

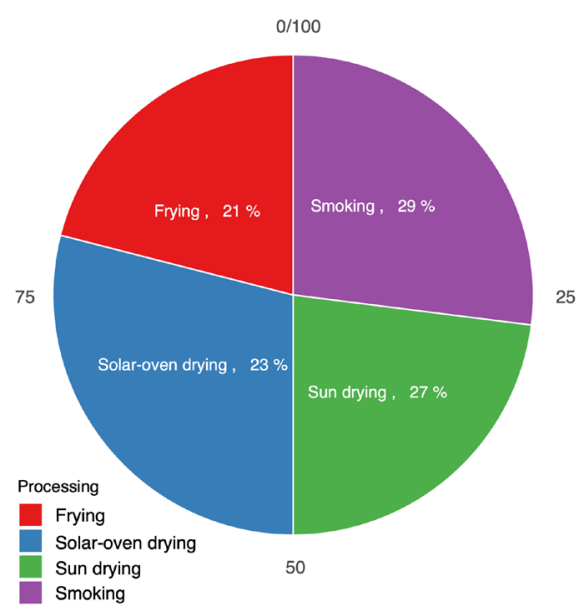

Figure 1. Effect of processing methods on texture of processed yellow croaker 
Table 2. Effect of processing methods on proximate composition yellow croaker

\begin{tabular}{|c|c|c|c|c|}
\hline Fish Products & $\begin{array}{l}\text { Moisture + SD } \\
\text { (g/100 g sample) }\end{array}$ & $\begin{array}{l}\text { Crude Protein + SD } \\
\text { (g/100 g sample })\end{array}$ & $\begin{array}{c}\text { Lipid + SD } \\
\text { (g/100 g sample) }\end{array}$ & $A s h+S D$ \\
\hline Sundried & $15.39+0.02 c$ & $69.05+0.05 c$ & $6.42+0.02 b$ & $8.15+0.02 b$ \\
\hline Fried & $30.44+0.04 a$ & $47.08+0.04 d$ & $18.58+0.02 \mathrm{a}$ & $3.55+0.01 d$ \\
\hline Solar dried & $14.13+0.03 d$ & $71.45+0.02 a$ & $4.43+0.03 c$ & $5.70+0.02 c$ \\
\hline Smoked & $16.03+0.05 b$ & $70.43+0.03 b$ & $2.72+0.02 d$ & $10.73+0.01 a$ \\
\hline
\end{tabular}

Values with different letter within each column are significantly different $(P<0.05)$

SD: Standard deviation

the standard methods of AOAC (1994).

\section{Statistical analysis}

Data collected on descriptive organoleptic assessment using hedonic scale were subjected to nonparametric test (Kruskal Wallis test) and data collected on proximate composition were subjected to analysis of variance (ANOVA) to determine significance between means. Duncan Multiple Range Test (DMRT) was used to compare differences among means. Significant level was chosen at $\mathrm{p}<0.05$.

\section{Results and discussion}

There was a significant difference between the odour of differently processed yellow croaker $\left(\chi^{2}=36.836, \mathrm{p}<0.01\right)$ with fried product, rated as having the best odour followed by smoked fish product (Table 1$)$. There was also a significant difference between the flavour $\left(\chi^{2}=40.705\right.$ $\mathrm{p}<0.01)$ of the various processed fish products with fried yellow croaker rated as having the best flavour followed by smoked product (Table 1). Ayeloja et al. (2013) reported similar result in their study of the effect of processing methods on nutritive value of catfish (Clarias gariepinus). The result of this study also agrees with the opinion of Jang et al. (2009). In their study of food attributes as reported that the satisfaction levels of ethnic foods varies depending on diverse food attributes such as taste, fresh, colorful, uniqueness and healthiness. In related veins, Lin (1991) observed that oyster consumption was mainly influenced by five food attributes, including taste, nutritional value, freshness, cost and safety. However, there was no significant difference $\left(\chi^{2}\right.$ $=3.932, \mathrm{p}>0.05$; Table 1$)$ in the perceived texture of the various fish products although there was a small preference for smoked fish, (29\%) over sundried fish product (27\%) and fried fish (21\%) (Fig.1).

The results of the effect of processing methods on proximate composition of yellow croaker (Table 2) indicated that processing methods showed effect on the proximate composition of processed yellow croaker. Ogbonnaya and Ibrahim (2009) also reported that different drying methods affected the proximate compositions of catfish. The moisture content of the various fish prod- ucts was significantly different $(\mathrm{P}<0.05)$ with fried fish having the highest moisture content $(30.44+0.04 \mathrm{~g} / 100$ g sample). A similar trend was observed for percentage lipid composition with fried fish product had the highest percentage of lipids $(18.58+0.02 \mathrm{~g} / 100 \mathrm{~g}$ sample). However, solar dried fish product had the highest crude protein $(71.45+0.02 \%)$ which was significantly different $(p<0.05)$ from the protein content of the other fish products, which suggests that proteins in solar dried fish product were retained and less denatured by processing method employed than in other processed fish products. Fried fish had the lowest percentage protein. This is in accordance with the findings of Gokoglu et al. (2004), Tao and Linchun (2008). There was a significant difference $(\mathrm{p}<0.05)$ in the percentage ash of the various fish products with smoked fish product having the highest ash content $(10.73+0.01 \mathrm{~g} / 100 \mathrm{~g}$ sample). Oyero et al. (2012) expressed a similar opinion that smoked fish products showed significant higher levels of ash content, which was as a result of inorganic matter which remains on it after the organic matter burnt. This signifies that the smoked fish products had high levels of mineral contents.

\section{Conclusion}

This study indicates that consumers prefer the odour and flavor of fried fish product above others followed by that of smoked fish product. On the other hand, solar-oven dried fish had the highest crude protein followed by smoked fish. Smoked fish had the highest percentage of ash which probably resulted from the burnt organic matter; this signifies that the smoked fish products had high levels of mineral matter. It is therefore better to process yellow croaker fish using solar oven or smoking as fish preserved using these preservation methods have better protein content. Consumers also preferred the odour and flavour of smoked fish above others; this additional value could increase the economic value of smoked fish and in turn increase the income of fishers.

\section{References}

Adebayo-Tayo, B.C., Onilude, A.A. and Patrick, U.G. (2008): Mycoflora of Smoke Dried Fishes Sold in Uyo, 
Eastern Nigeria. World Journal of Agricultural Science. 4(3): 346 - 350.

Adeleye, O.A. (1993). Conservation Needs of Fisheries Resources and Reorientation for Sustainable Captive and Culture Practices. In Proceedings of the 10th Annual Conference Fisheries Society of Nigeria (FISSON), 16-20 November, 1992, Abeokuta, Nigeria. Pp: 230-234.

Afolabi O.A., O.A. Arawomo and O.L. Oke, (1984). Quantity changes of Nigeria traditional processedfreshwater species: nutritive and organoleptic changes. J. Food Technol., 19: 333-340.

Association of Official Analytical Chemists (1994). Official Methods of Analysis of the Association of Official Analytical Chemist, Vols. I and II, Association of Analytical Chemist, Arlington. 1298pp.

Ashraf, M. A.; Zafar, A.; Rauf, S.; Mehboob and. Qureshi, N. A. (2011). Nutritional values of wild and cultivated silver carp (Hypophthalmichthys molitrix) and grass carp (Ctenopharyngodon idella). Int. J. Agric. Biol., 13: $210-214$.

Ayeloja, A. A.; George, F.O.A.; Akinyemi, A. A.; Jimoh, W. A.; Dauda, T. O. and Akinosho, G. A. (2013). Effect of Processing Methods on Nutritive Value of Catfish (Clarias gariepinus).Journal of Food Science and Quality Management. 11: 31 - 38.

Castrillon, A.M., Navarro, P. and Alvárez-Pontes, E. (1997). Changes in chemical composition and nutritional quality of fried sardine (Clupea pilchardus) produced by frozen storage and microwave reheating. J. Sci. Food and Agric. 75: 125-132.

Emere, M. C. and Dibal, D. M. (2013). A survey of the methods of fish processing and preservation employed by artisanal fishermen in Kaduna city. Journal of Food Science and Quality Management. 11: 16 22.

Eyo, A. A. (2001). Fish Processing Technology. In The Tropics. Published by University of Illorin Press, Nigeria.

Eves, A. and R. Brown, (1993). The effect of traditional drying processes on the nutritional values of fish. Tropical Sci., 33: 183-189.
Foran, J.A.; Carpenter, D. O.; Hamilton, M.C.; Knuth, B.A. and Schwager, S.J., (2005).Riskbased consumption advice for farmed Atlantic and wild pacific salmon contaminated with dioxins and dioxinlike compounds. Journal of Environmental health perspective. 33:552-556.

Gokoglu, N.; Yerlikaya, P. and Cengiz, E. (2004). Effects of cooking methods on the proximate compositionand mineral contents of rainbowtrout (Oncorhynchus mykiss). Journal of Food Chem., 84: 19-22.

Jang. S. S. C., Ha, A., and Silkes, C. A. (2009). Perceived attributes of Asian foods: From the

perspective of the American customers. International Journal of Hospitality

Management, 28 (1), 63-70.

Lin, J. (1991). Consumer food attribute perceptions and consumption behavior.Consumer Interests Annual 1991.

Ogbonnaya, C. and Ibrahim, M. S. (2009). Effects of drying methods on proximate compositions of catfish(Clariasgariepinus). World Journal of Agricultural Sciences.

5 (1): 114-116.

Oyero J.O.; Sadiku, S. O. E. and Eyo, A. A. (2012).The effect of various smoking methods on the quality ofdifferently salted Oreochromis niloticus. International Journal of Advanced Biological Research. 2(4): $717-723$.

Schiffman, S. S. and Graham, B. G. (2000) Taste and smell perception affect appetite and immunity in the elderly. European Journal of Clinical Nutrition. 54 (3): $54-63$.

Tao, W. and Linchun, M. (2008). Influences of hot air drying and microwave drying on nutritional andodorous properties of grass carp (Ctenopharyngodon idellus) fillets. Journal of Food Chem., 110 (3): 647-653.

Tobor, T. G. (1994). Fish production and Processing on Nigeria. NIOMR Tech. Paper. 